\title{
HADIS SEBAGAI SUMBER HUKUM ISLAM: (Tinjauan Paham Inkar As-Sunnah, Syi’ah, dan Orientalis)
}

\author{
Kaharuddin dan Abdussahid \\ Institut Agama Isalam (IAI) Muhammadiyah Bima \\ kaharuddinniam@gmail.com
}

\begin{abstract}
Abstrak
Islam merupakan sistem nilai dan ajaran illahiyah yang bersifat transendental. sehubungan dengan hal itu, ajaran Islam sebagai sesuatu sistim universal akan selalu hadir dinamis dan selalu mampu menjawab berbagai tantangan zaman. Kondisi tersebut didasarkan pada keberadaan sumber ajaran Islam yang kokoh, yaitu Al-Qur'an, dan Hadist. Al-Qur'an adalah firman Allah SWT yang di dalamnya terkandung ajaran pokok untuk keperluan seluruh aspek kehidupan. Sedangkan Hadist/Sunnah merupakan segalah sesuatu yang disandarkan kepada Nabi Muhammad SAW yang berisi petunjuk (pedoman) untuk kemaslahatan hidup umat manusia. Namun berbeda dengaan Al-Qur'an, perkembangan Hadist/Sunnah tidak semulus Al-Qur'an. Berbagai keraguan bahkan penolakan muncul seiring pertumbuhan studi terhadap Hadist/Sunnah itu sendiri. Keraguan terhadap hadits, lebih memuncak ketika munculnya golongan yang mengingkari Sunnah (inkar As Sunnah) diantaranya; kaum Syi'ah yang cenderung memberikan penafsiran yang menyimpang tentang kemurnian hadis Nabi. Bahkan pada sisi yang lain, muncul pula pandangan para tokoh orientalis yang menganggap hadis sebagai sumber terpercaya awal masa Islam, melainkan hanya sebagai sumber dogma, konflik serta perhatian muslim belakangan yang telah menyebarkan hadis.
\end{abstract}

Kata Kunci: Hadist, Inkar As-Sunnah, Syi'ah, dan Orientalis

\section{Pendahuluan}

$\mathrm{I}$ slam sebagai agama samawi memiliki sumber ajaran, yaitu al-Qur'an dan Nabi Muhammad SAW sebagai pembawa risalah diberikan kewenangan oleh Allah SWT untuk menjelaskan kepada umatnya tentang wahyu yang diterimanya, dan penjelasan Nabi tersebut dikenal dengan istilah hadis Nabi. ${ }^{1}$ Sebagian besar kaum muslimin meyakini bahwa Hadis adalah kendaraan sunah Nabi dan bahwa hadis merupakan tuntunan yang tidak dapat diabaikan dalam memahami wahyu Allah SWT. Sebagai salah satu sumber otoritas Islam kedua setelah al-Qur'an, sejumlah literatur hadis memiliki pengaruh yang sangat menetukan serta menjadi sumber hukum dan inspirasi agama ${ }^{2}$ Para ulama telah berupaya keras mengumpulkan dan mengklasifikasi serta memilah hadis yang

${ }^{1}$ Muhammad Sabir Maidin, Ingkar Sunah Atau Hadis Dalam Perspektif Historis ( Makassar: Alauddin Pers, 2012), 83.

${ }^{2}$ Kamaruddin Amin, Menguji Kembali Keakuratan Metode Kritik Hadis (Jakarta selatan: PT Hikmah, 2009), 1. 
autentik dan yang palsu. Di satu sisi, para sarjana muslim belajar hadis lebih didorong oleh peran sentral yang dimainkan oleh hadis sebagai sumber hukum dan doktrin teologis, sedangkan serjana barat mempelajari hadis pada dasarnya didorong oleh kepentingan sejarah (historis interest). ${ }^{3}$ Dalam pendekatan historiografi, pertumbuhan hadis telah terjadi pada masa Rasulullah SAW, selanjutnya dikembangkan oleh para sahabat, tabi'in samapai dapat dikumpulkan menjadi sebuah kitab. Hadis tidak seperti al-Qur'an yang dikumpulkan dalam sebuah mushaf, hadis dikumpulkan oleh banyak penulis berdasarkan hafalan dan pengetahuanya. Oleh sebab itu, hadis-hadis Nabi Muhammad SAW terkumpul beberapa kitab yang disusun oleh masing masing mukharrij atau penulis. ${ }^{4}$

Proses perkembangan hadis barlangsung dari satu generasi kegenerasi berikutnya. Hadis berkembang dalam kurun waktu bertahun-tahun dan berabad yang lalu, sehingga muncul keraguan dan kecurigaan pada riwayat tertentu atau orang tertentu. ${ }^{5}$ Mulai abad ke-19, pertanyaan tentang autensitas, originalitas, asal muasal, keakuratan serta kebenaran hadis, muncul dan menjadi isu pokok dalam srtudi Islam. Pertanyaan ini muncul dari para sarjana Barat dan juga sarjana Muslim. Abu Rayyah misalanya, berpendapat bahwa hadis Nabi telah rusak dan kata-kata persisya telah hilang karena riwayah bi al-ma'na (periwayatan secara makna, bukan hafal). Gustav Weil menyarankan sarjana Barat untuk menolak paling tidak separuh hadis yang terdapat dalam Shahih Al-Bukhari. Selain itu, ada juga sarjana barat seperti, Alois Sprenger yang menyatakan keragu-raguanya terhadap kepercayaan (Tsiqah) hadis sebagai sumber sejarah. Kesarjanaan hadis eropa mencapai puncak dalam karya Ignaz Goldziher, dan menjadi karya kritik hadis terpenting pada abad ke-19. Ia tidak menganggap hadis sebagai sumber terpercaya awal masa Islam, melainkan hanya sebagai sumber yang sangat bernilai sebagai dogma, konflik serta perhatian muslim belakangan yang telah menyebarkan hadis. ${ }^{6}$ Keraguan tersebut lebih memuncak ketika munculnya golongan yang mengingkari Sunnah (inkar As Sunnah). Kelompok memiliki argumentasi sendiri atas sikap mereka itu. Berdasarkan asumsi teoritis tersebut, tulisan ini berusaha menjelaskan berbagai macam aspek tentang hadis yang berkaitan posisinya sebagai sumber hukum setelah Al-Qur'an dan munculnya beberapa golongan yang salah paham tentang hadis sebagai sumber hukum Islam.

\section{Pemaknaan Terhadap Hadis}

Menurut Ibn Manzhur, kata "al-hadis", jamaknya, "al-ahdis", al-haditsan, dan al-haditsan, dan al-hutsan.. menurut bahasa, kata "al-hadit" mencakup: Al-

${ }^{3}$ Ibid.

${ }^{4}$ Ambo Ase, Ilmu Hadis Pengantar Memahami Hadis Nabi SAW (Makassar: Alauddin Pers, 2010), 132.

${ }^{5}$ Ibid.

${ }^{6}$ Kamaruddin Amin, Menguji Kembali Keakuratan Metode Kritik Hadis,...2. 
Jadid, lawan Qadim artinya yang baru (jamaknya hidats, hudatsa, dan hudits), AlKhabar, yang artinya berita; dan Al-Qarib, artinya dekat. Adapun pengertian hadis secara terminologis menurut ahli hadis adalah segala ucapan, perbuatan dan segala keadaan atau perilaku Nabi SWA. ${ }^{7}$ Dalam definisi diatas menyatakan bahwa yang termasuk dalam kategori hadis adalah perkataan (Qauliyah), perbuatan (fi'liyah), dan keadaan (ahwaliyah) Nabi SAW. Di samping itu, sebagai ahli hadis menyatakan bahwa, masuk juga ke dalam keadaanya, segala yang diriwayatkan dalam kitab sejarah (shirah), kelahiran dan keturunannya (silsila) serta tempat dan yang bersangkut paud dengan itu, baik sebelum diangkat menjadi Nabi/ Rasul, maupun sesudahnya. Sebagian ulama seperti Ath-Thiby berpendapat bahwa "hadis itu melengkapi sabda Nabi, perbuatan, ketetapan Nabi melengkapi perkataan, perbuatan, dan ketetapan sahabat. Sebagaimana melengkapi perkataan, perbuatan, dan ketetapan tabi'in. maka sesuatu Hadis yang sampai kepada Nabi dinamai marfu', yang sampai kepada Sahabat dinamai mauquf dan yang sampai kepada tabi'in dinamai maqthu. ${ }^{8}$

\section{Pengertian Sunah, Khabar dan Atsar}

Di samping itu ada beberapa kata yang bersinomim dengan kata hadits seperti Sunah, Khabar dan Atsar. Pada aspek ini kebanyakan ulama mengertikan sama kepada tiga istilah ini. Namun sebagian yang lain membedakannya dan dapat dijabar sebagai berikut ini:

\section{Sunnah}

Secara etimologi, kata as-sunnah dapat diartikan sebagai al thariqah atau al sairah yaitu jalan'. Menurut Nuruddin 'atar, pengertian sunnah menurut bahasa berarti: "jalan kebiasaan yang baik ataupun yang jelek" Menurut bahasa sunah bermakna jalan yang dijalani, baik terpuji atau tidak. Sesuatu yang tidak tradisi atau menjadi kebiasaan dinamai sunnah, walaupun tidak baik. ${ }^{10}$ Sunnah menurut muhaditsin ialah segala sesuatu yang dinukilkan dari Nabi SAW, baik berupa perkataan, perbuatan, maupun berupa taqrir, pengajaran, sifat, kelakuan, perjalanan hidup baik yang demikian itu sebelum Nabi SAW, maupun sesudahnya. ${ }^{11}$

Dalam kaitannya dengan istilah hadits, bbaik dari sudut etimologi maupun terminology antara sunnah dan hadits memiliki perbedaan, sebagaimana yang

${ }^{7}$ Lihat Mahmud, At-Thahha. Ushul al Takhrij wa Dirasatu al Asaanid (Riadh: Maktabah al-Rusydi, 1983), 155

${ }^{8}$ Habi Asshiddiqy, .... 23

${ }^{9}$ Mahmud al Thahhan, Tafsir Musthalh al Hadis (Surabaya: Sirkat Bungkul Indah, 1985), 4.

${ }^{10}$ Endang Soetari, Ilmu Haidis: Kajian Riwayat dan Dirayah (Bandung: Mimbar Pustaka, 2005), 6 .

${ }^{11}$ M. Agus Salahudin dan Agus Suyadi, Ulumul Hadias (Bandung; Pustaka Setia, 2009), 19 
diungkapkan oleh Subhi Shalih dan Endang Soetari Ad. Bahwa antara hadits dan sunnah dapat dibedakan, bahwa hadits konotasi adalah segala segala peristiwa yang dinisbahkan kepada Nabi SAW walaupun hanya satu kali beliau mengucapkan dan mengerjakannya. Sedangkan sunnah, adalah sesuatu yang diucapkan atau dilaksanakan secara terus menerus dan dinukilkan dari masa ke masa dengan jalan muttawatir.

\section{Khabar}

Khabar menurut etimologi ialah berita yang disampaikan dari seseorang. Jamaknya adalah akhbar, orang banyak menyampaikan khabar dinamai khabir. Khabar digunakan untuk segala sesuatu yang diterima dari yang selain Nabi SAW. Mengingat hal inilah orang yang meriwayatkan hadits dinamai muhaddits, dan orang yang meriwayatkan sejarah dinamai akhbary. Oleh karenanya, menurut mereka, khabar berbada dengan hadits.

\section{Ta'rif Atsar}

Atsar menurut etimologi, ialah bekasan sesuatu atau sisa dari sesuatu. Dan nukilan (yang dinukilkan), sesuatu do,a umpamanya yang dinukilkan dari Nabi dinamai do,a ma'tsur. Menurut terminology, jumhur ulama menyatakan bahwa atsar sama artinya dengan khabar dan hadits. Sebagaimana ulama mengatakan atsar lebih umum dari pada khabar, yaitu atsar berlaku bagi segala sesuatu dari Nabi saja. Dengan memperhatikan definisi-definisi tersebut terdapat perbedaan, namun kita dapat mengartikan bahwa hadits, khabar, sunnah maupun atsar pada prinsipnya sama-sama bersumber dari Rasulullah.

\section{Fungsi Hadits Terhadap Al- Qur'an}

Hadits Nabi SAW merupakan penafsiran dalam praktek-praktek penerapan ajaran Islam secara factual dan ideal, dan umat Islam diwajibkan mengikuti hadits sebagaimana diwajibkan mengikuti Al-quran. Dan hadits mempunyai beberapa fungsi, diantaranya: ${ }^{12}$

a. Hadits berfungsi sebagai bayan al - Tafshili, yaitu menjelaskan atau memerinci ke mujmalan Al-Quran sehingga dapat dipahami umat Islam. Contoh perintah sholat yang ada dalam Al-Qur'an (Surah Al-Baqarah ayat: 43 ) berikut ini:

$$
\text { و اقيم الصـلوة واتو الزكوة واركـو ا مع الر اكعين (البقرة) }
$$

Artinya : Dan dirikanlah shalat, dan tunaikanlah zakat dan ruku'lah bersama orang-orang yang ruku.

Makna Ayat di atas hanya berbicara secara umum tentang shalat, sedangkan tata cara pelaksanaan shalat tidak dijelaskan di dalam ayat tersebut,

${ }^{12}$ Munzeir Suprapta, Ilmu Hadis (Jakarta: Raja Grafindo Pustaka, 2003), 61-63 
maka hal ini dijelaskan oleh Rasullah SAW di dalam Hadits beliau, sebagaimana sabda Beliau yang berbunyi :

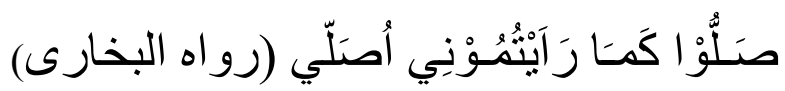

Artinya: Shalatlah sebagaimana kamu melihat aku shalat (HR. Bukhori)

b. Hadits berfungsi sebagai bayan al Takid, yakni memperkuat dasar hukum yang telah ditetapkan dalam Al- Quran, yakni dengan cara mengulangi apa yang dikatakan dalam Al- Quran, seperti perintah Allah dalam Al-Qur'an dalam Surah Al-Baqarah sebagai berikut: "Karena itu, barang siapa yang mempersaksikan pada waktu itu bulan, hendaklah ia berpuasa.... (Q.S. AlBaqarah/2: 185). Ayat Al-Qur'an ini juga di Ta'kid (di perkuat) oleh hadis Nabi SAW, yakni; Apabila melihat (ru'yat) bulan, maka berpuasalah. Dan begitu pula apabila melihat (ru'yat) bulan itu maka, berbukalah (HR. Muslim)

c. Hadits berfungsi sebagai bayan al muthlak, yakni memberikan batasan-batasan dari dalil Al-Quran yang masih berbentuk dalil mutlaq, seperti laki-laki dan perempuan yang mencuri. Sebagaimana Allah SWT jelaskan dalam Al-Qur'an Surat Al-Maidah beriku ini: "Laki-laki dan perempiuan yang mencuri, potonglah tangan keduanya (sebagai) pembalasan bagi apa yang mereka kerjakan dan sebagai siksaan dari Allah. Dan Allah maha perkasa dan bijaksana. (Q.S. Al-Maidah/5: 38). Tedapat pula Hadis Nabi SAW yang menyatakan: "Tangan pencuri tidak boleh dipotong, melainkan (mencuri sebilai) seperempat dinar atau lebih. (Mutafaqqun menurut lafaz Muslim).

d. Hadits berfungsi sebagai bayan al takhsis, yaitu menjelaskan ayat Al-Quraan yang masih bersifat aam (umum) seperti dalam pemberian harta waris kepada anak laki-laki dan perempuan bagi orang tua. Yang sudah meninggal tapi Rasul membatasi dengan ketentuan bahwa anak yang membunuh tidak bisa menerima warisan dari orang tua yang ia bunuh. Sebagaimana di jelaskan dalam Al-Qur'an dalam Surah. An-Nisa 11: "Allah menyari'atkan bagimu tentang pembagian pusaka untuk anak-anakmu, yaitu: bagian seorang anak laki-laki sama dengan bagian dua anak perempuan.(Q.S. An-Nisa 11). Di perkuat oleh hadis Nabi, yakni "Seorang pembunuh tidak berhak menerima harta warisan".(HR. Ahmad)

e. Hadits berfungsi sebagai bayan tasyri yaitu menetapkan suatu hukum yang tidak disebut dalam Al-Quran secara jelas seperti penentuan hukum zakat fitrah, sebagaimana Hadis Nabi yang Artinya: "Bahwasanya Rasulullah SAW telah mewajibkan zakat fitrah kepada umat Islam pada bulan Ramdhan satu sukat (Sha') kurma atau gandum untuk setiap orang baik merdeka atau hamba, laki-laki atau perempauan Muslim”. (HR. Muslim). 
f. Hadits berfungsi sebagai bayan al nash yaitu berfungsi menghapus hukumhukum yang terdapat dalam al-quraan seperti disebutkan dalam al-quran bagi orang yang sudah ada tanda-tanda kematian hendaknya memberikan wasiat kepada ibu bapak dan kerabatnya, namun din ash dengan hadits Nabi" tidak ada wasia untuk pemberi waris". (tentang ini masih banyak diperdebatkan para ahli hukum dan hadits).

\section{Pandangan Inkarussunah Terhadap Hadits}

Inkarussunah adalah golongan golongan yang meragukan kehujjahan dan menolak hadits sebagai sumber hukum ke dua setelah al-quran dalam menjalankan syariat Islam. Menurut, As Syafii membagi inkarussunah menjadi tiga golongan yakni:

1. Golongan yang menolak assunah secara keseluruhan, dengan argumen bahwa al-quran adalah kitab suci yang berbahasa arab yang sudah dipahami oleh orang arab sendiri uslub uslubnya, karenanya tidak perlu penjelasan melalui assunah. Alasan lainnya adalah al-quran sudah mencakup seluruh hal yang dibutuhkan dalam kehidupan manusia maka dari itu tidak perlu tambahan dasar huku dalam beragam Islam.

2. Golongan yang menolak assunah kecuali yang memiliki kesamaan dengan petunjuk al-quran karena mereka beranggapan bahwa al-quran sebagai masda Al Awwal al kulli yaitu sumber hukum yang pertama bersifat universal bagi syariat Islam.

3. Golongan yang menolak assunah yang berstatus ahad, dengan alasan bahwa hadits ahad tingkatannya hanya sampai pada dzanny, ada kemungkina perawiperawi dari hadits ahad tersebut lupa atau berbuat salah, dan sejarah teah membuktikan banyaknya pembuat hadits hadits palsu untuk kepentingan politik, golingan dan dunia lainnya. Yang termasuk dalam golongan ini adalah Qodariyah, Rafidhah dan madzhab adzohiri.

\section{Pandangan Syiah Terhadap Hadits}

Diskursus hadits dalam wacana keilmuan Syiah telah mempunyai akar yang panjang dan dilakukan dengan cukup intens. Perhatian mereka terhadap hadits/sunnah, menurut sebagian orang membuat mereka berhak pula untuk menyandang gelar Ahlu Sunnah Wa Syiah. Menurut Dr. Muhamad At-Tijani asSamawi seorang Sunni yang kemudian membelot ke Syiah ketika melakukan kajian komparatif antara sunnah dan syiah memberikan judul bukunya tersebut, Asy-Syiah Hum Ahlu Sunnah. Namun demikian, dalam beberapa hal, metodologi hadits Syiah amat berlainan dengan metodologi Ahlu Sunnah. Kajian tentang metodoligi hadits dalam Syiah imamiah telah menjadi objek sebuah risalah doktor di Fakultas Ushuluddin Universitas al Azhar. Pada penghujung tahun 1996, risalah tersebut telah diuji dan dinyatakan lulus. 


\section{Term Hadits dalam Syiah}

Hadits atau sunnah, secara terminologis, menurut ulama ilmu hadits Ahlu Sunnah Wa Al Jamaah adalah seluruh hal yang diriwayatkan dari Rasulullah SAW, baik perkataan, perbuatan, persetujuan, sifat fisik maupun akhlak dan sirah beliau. Sedangkan dalam wacana keilmuan Syiah, perkataan imam-imam Syiah (yang masyhum, menurut kaum Syiah) juga bersatu seperti Hadits dan diterima seperti Al-Quran. Sedangkan menurut M.H. Al Kasyif al Githa, imam atau imamah adalah kedudukan Ilahiah yang Allah SWT pilihkan bagi hambanya, sesuai dengan ilmu Allah SWT, seperti memilih para Nabi. Bahkan pandangan telogis kaum Syiah menyatakan bahwa Allah SWT telah memerintahkan Nabi Muhammad SAW, untuk menunjukan imam kepada umat dan memerintahkan mereka untuk mengikutinya. Adapun substansi Khabar, Hadist dan riwayatriwayat tersebut menurut kaum Syi'ah terbagi menjadi tiga macam. Pertama, khabar dan riwayat yang mengandung petunjuk pembersihan jiwa, akhlak, nasehat dan cara-cara pengobatan penyakit hati. Dengan muatan berisi pertakut, ancaman, dan dorongan. Atau yang berkaitandengan tubuh, seperti kesehatan, penyakit, sakit dan pengobatan. Juga manfaat buah-buahan, tetumbuhan, pepohonan, air dan batu mulia. Atau yang mengandung do'a, zikir, jampai dan keutamaan ayat-ayat. Serta semua hal yang disunnahkan, baik dalam pembicaraan, perbuatan, maupun sikap. Itu semua, menurut kaum Syi'ah, bisa dijadikan landasa untuk beramal ibadah. Dan tidak perlu mencari tahu apakah sanad dan matannya shahih atau tidak. Kecuali jika ada tanda-tanda yang menunjukkan kepalsuannya.

Kedua, yang mengandung hukum syara' parsial, Taklifi atau Wadl'i. seperti thaharah, berwhudu, cara shalat, zakat, khumus, jihad dan semua bagian mu'amalat ,transaksi yang diperbolehkan. Juga tentang nikah, Thalaq, warisan, hudud dan diyat. Semua khabar dan riwayat tersebut tidak boleh langsung dijalankan. Namun diberikan kepada faqih yang mujtahid untuk menterjemahkannya. Sedangkan orang awam harus mengikuti mujtahid marji'. Ketiga, khabar dan riwayat yang mengandung pokok-pokok aqidah, seperti pengisbatan al khaliq, juga tentang hasyr, barzakh, sirath, mizan, hisab dan lainlain. Khabar dan riwayat seperti ini, jika berkaitan dengan aqidah dan pokok agama seperti tauhid, ' $a d l$, nubuwwah, imamah dan $m a$ ' $a d$, jika khabar tersebut sesuai dengan dalil-dalil 'aqli, urgensi, dan tanda-tanda yang qath' $i$, maka ia dapat dijalankan, dan tidak prlu menyelidiki sanad, keshahihan dan ketidak shahihannya.

\section{Klasifikasi Hadits dalam Syiah}

Hadits, menurut Syi'ah terbagi menjadi dua bagian, muttawatir dan ahad. Hadits mutawattir adaah hadits yang diriwayatkan oleh sebuah jama'ah yang mencapai jumlah yang amat besar sehingga tidak mungkin mereka berbohong dan salah. Hadits seperti ini adalah hujjah dan harus dijadikan landasan dalam 
beramal. Sedangkan hadits ahad adaah hadits yang tidak mencapai derajat tawatur, rawie yang diriwayatkannya satu atau lebih 48. Kemudian, hadits ahad diklasifikasian menjadi empat bagian antara lain: 1) Shahih, yaitu hadits yang diriwayatkan oleh seorang penganut Syi'ah imamiah yang telah diakui ke-adalahannya dan dengan jalan yang shahih. 2) Hasan, yaitu jika rawi yang meriwayatkannya adalah seorang syi'ah imamiah yang terpuji, tidak ada seorangpun yang jelas mengecamnya atau secara jelas mengakui ke-adalah-annya. 3) Muwats-tsaq, yaitu jika rawie yang meriwayatkannya adalah bukan syi'I, namun ia adalah orang yang tsiqat dan terpercaya dalam periwayatan. 4) Da'if, yaitu hadits yang tidak mempunyai kriteria-kriteria tiga kelompok hadits di atas, seperti misalnya sang rawie tidak menyebutkan seluruh rawie yang meriwayatkan hadits kepadanya. Hadits Shahih adalah hujjah menurut kesepakatan seluruh ulama syi'ah yang mengatakan bahwa khabar ahad adalah hujjah. Sedangkan hadits muwats-tsaq dan hasan, menurut pendapat yang masyhur keduanya adalah hujjah, sedangkan menurut pendapat pendapat kedua mengatakan bahwa keduanya tidak dapat dijadikan hujjah. Adapun hadits Da'if, menurut kesepakatan seluruh ulama syi'ah tidak dapat dijadikan hujjah.

\section{Pandangan Orientalis Terhadap Hadits}

Orientalis berasal dari kata "orient" yang berarti Timur, orientalis berarti orang yang belajar tentang budaya, peradaban dan agama Negara-negara timur. Orientalis dalam bahasa ini dimaksudkan adalah orang-orang yan mempelajari tentang budaya orang timur khususnya mempelajari agama Islam untuk menghacurkan ajaran Islam itu sendiri dari keyakinan umatnya di Negara-negara timur. ${ }^{13}$ Kajian-kajian orientalis terhadap Islam, khususnya hadits dapat dipetakan menjadi tiga kelompok asumsi, antara lain: Pertama, Asumsi Skeptis yaitu yang meragukan otentisitas hadits dengan tokoh terkenal seperti Ignaz Godziher yang berpendapat bahwa "Bagian terbesar dari suatu hadits tidak lain adalah hasil perkembangan Islam pada abad I dan II, baik dalam bidang keagamaan, politik, maupun sosial. Tidaklah benar bahwa hadits merupakan dokumen Islam yang ada pada masa dini, melainkan pengaruh dari perkembangan Islam pada masa kematangan. Artinya Goldziher berpendapat bahwa hadits adalah bantuan ulam abad I dan abad II $\mathrm{H}$.

Kedua, Asumsi non Skeptis yaitu tidak meragukan otentisitas hadits. Tokoh pendukung dari pendapat ini adalah Nabia Abbot, seorang guru besar di Universitas Chicago USA. Ia berkesimpilan bahwa terhadap bukti-bukti konkrit yang menunjukan adanya pencatatan dan penilasan hadits sejak abad pertama hijriyah, ini disebabkan oleh tradisi umat Islam dalam tulis menulis, tidak benar pendapat yang mengatakan bahwa hadits adalah bentuk pemalsuan dalam Islam.

\footnotetext{
${ }^{13}$ Lebih lengkap tentang perkembangan orientalisme,
} 
Dalam penelitiannya Abbot juga mendapatkan bukti bahwa banyak data sejarah yang menghimpun informasi tentang karya-karya generasi awal Islam yang bersumber dari berbagai kitab, meskipun informasi tersebut belum tentu di dukung dengan adanya manuskrip. Dengan demikian tradisi menulis termaksuk didalamnya penulisan hadits Nabi merupakan penopang tradisi lisan yang berkembang pada masyarakat arab di masa itu. Ketiga, Asumsi Middle Ground yaitu asumsi yang menengahi dua teori yang berlawanan tersebut di pelopori oleh Harald Mitzki seorang professor hadits di Universitas Nijmegen Belanda, dia mengkritik asumsi skeptic Schacht dan Junynboll dengan mengatakan bahwa otenttisitas hadits terbukti sejak abad pertama hijriyah. Bagi motzki al-quran dan hadits sudah dipelajari sejak abad 2 hijriyah atau bahkan sejak Nabi masih hidup, dan para fuqoha Hijaz terbukti telah menggunakan hadits-hadits sejak pertama hijriyah. Berdasarkan hasil analisisnya atas sanad maupun mata Abdul Razaq Al Shan ani (w. 211H/826M), Motzki berkesimpulan bahwa kecil sekali kemungkinan terjadinya keberagaman data periwayatan itu hasil pemalsuan yang terencana. Sanad dan matan hadits-hadits dalam kitab tersebut layak dipercaya.

Menurut pandangan Daud Rsyid, adapun tujuan kaum orientalis bukan semata-mata demi ilmu dan penelitian belaka, namun memiliki misi menghancurkan sumber doktrinal Islam. Dalam Fahm al-Sunnah fi al-Jami'ah alMusyatsyarikun fi al-Gharb, ia memberikan ciri-ciri karya orientalis Barat dalam memaknai hadits sebagai berikut:

a. Didasari sikap buruk sangka, baik terhadap landasan-landasan, nilai-nilai, maupun hal lain yang berkaitan dengan Islam (su'uzhan al-fahm li-kulli mayattashilu bi al-Islam), sehingga hasil-hasil penelitian dan karya-karya mereka adalah keraguan terhadap Islam (syak) dan kesimpulan-kesimpulan yang mereka buat keliru (khatha).

b. Didasari sikap buruk sangka terhadap para ulama Islam serta para pemimpin Muslim (su'uzhan bi rijal al-muslimin wa ulama'ihim wa'uzhama'ihim), sehingga tidak ada ajaran-ajaran Islam yang dapat diterima oleh mereka.

c. Memberikan gambaran bahwa masyarakat Islam adalah masyarakat yang senang berselisih atau berada pada periode peperangan (tashawwur almujtama' al-islam fi mukhtalif al-'ushur/mujtama' al-mutafak). Kesan ini terutama ditujukan pada masa-masa awal Islam, pertentangan-pertentangan kecil dibesar-besarkan. Seperti pertentangan antara Ali ra, dengan Mu'awiyyah ra serta antara Ali ra dengan Aisyah ra.

d. Melukiskan kebudayaan atau peradaban Islam dengan gambaran yang tidak sesuai, ditambahi penyimpangan-penyimpangan dan khayalan-khayalan mereka disana-sini (tashawwur al-hadharat al-islamiyyat tashawwuran duna waqi'in). Seperti kitab-kitab yang mereka gunakan acuan dalam sejarah Islam 
mereka ambil dari kitab-kitab karangan para pujangga dan penyair. Dan tidak mengambil dari sumber yang sahih.

e. Melihat Islam dari sisi pertentangannya saja atau bodoh terhadap sifat masyarakat Islam yang hakiki (al-jahl bi thabi'at al-mujtama al-Islam 'ala haqiqatih). Mereka meihat masyarakat Islam dengan menyamakannya dengan bangsa-bangsa mereka zaman dahulu.

f. Sudah lebih dulu membuat prakonsepsi batasan-batasan terhadap nash-nash Islam, yang disesuaikan dengan pemikiran mereka (ikhdha'I al-nushush li fikratihim). Seperti ayat all-quran mereka tafsirkan sendiri, makna hadits mereka tafsirkan sendiri disesuaikan dengan fitrah mereka.

g. Mengadakan penyimpangan terhadap nash-nash baik yang tekstual maupun kontekstual (maksudnya) dan jika tidak dapat juga mereka simpangkan secara tidak langsung karena jelasnya makna nash tersebut, maka mereka melakukannya dengan melalui perumpamaan-perumpamaan (tahrifuhum li alnushush min al-ahyan maqshudan bi al-ibarat).

h. Memberikan status hukum sendiri terhadap referensi-referensi keislaman (tahakkumuhum li al-mashadir), artinya mereka menentukan sendiri standar bagi referensi-referensi Islam tersebut. Seperti mensahihkan kitab al-hayawan karangan ad-damiri sebagai kitab hadits sahih, padahal kitab itu tentang bahasa Arab. Selanjutnya di sisi lain mendustakan kitab al-Muwathatha karangan Imam Malik, padahal kitab ini merupakan kitab induk hadits-hadits sahih. Dalam mempelajarin fiqh Islam, mereka gunakan kitab-kitab tarikh seperti Tarikh al-Thabari, al-Sirah karangan Ibnu Hasyim.

\section{Penutup}

Berdasarkan deskripsi uraian di atas, dapat dipahami bahwa perkembangan hadist Nabi Muhammad SAW sebagai sumber ajaran Islam juga dihadapkan dengan munculnya beragam pandangan pro dan kontra terkait urgensinya hadist sebagai pedoman hukum Islam. Bahkan diskursus tentang keberadaan hadis sebagi sumber ajaran Islam cenderung menguat seiring dengan muncul pandangan kritis dari beberapa kelompok antara lain; paham Inkar As-Sunnah, kaum Syi'ah, dan kelompok Orientalis yang memiliki pendapat yang berbeda tentang keberdaan hadist. Inkarussunah merupakan golongan yang meragukan kehujjahan dan menolak hadits sebagai sumber hukum ke dua setelah Al-Qur'an dalam menjalankan syariat Islam. Syiah, menganggap perkataan imam-imam Syiah (yang masyhum, menurut kaum Syiah) juga bersatu seperti hadits dan diterima seperti Al-Quran. Pandangan telogis kaum Syiah juga menyatakan bahwa Allah SWT telah memerintahkan Nabi Muhammad SAW, untuk menunjukan imam kepada umat dan memerintahkan mereka untuk mengikutinya. Selanjutnya, kelompok orientalis mengungkapkan asumsi skeptis yang meragukan otentisitas hadits dengan tokoh terkenal seperti Ignaz Godziher yang berpendapat bahwa "Bagian terbesar dari suatu hadits tidak lain adalah hasil perkembangan Islam 
pada abad I dan II, baik dalam bidang keagamaan, politik, maupun sosial. Tidaklah benar bahwa hadits merupakan dokumen Islam yang ada pada masa dini, melainkan pengaruh dari perkembangan Islam pada masa kematangan. Selain itu, ada juga sarjana Barat seperti, Alois Sprenger yang menyatakan keragu-raguanya terhadap kepercayaan (Tsiqah) hadis sebagai sumber sejarah dalam ajaran Islam.

\section{Daftar Pustaka}

Amin, Kamaruddin. Menguji Kembali Keakuratan Metode Kritik Hadis. Jakarta Selatan: PT Hikmah, 2009.

Ase, Ambo. Ilmu Hadis Pengantar Memahami Hadis Nabi SAW (Cet. I; Makassar: Alauddin Pers, 2010.

Departeman Agama RI, Al-Qura'an Tajwid dan Terjemahan. Solo: Penerbit Abyan, 2014.

Mahmud. At-Thahha. Ushul al Takhrij wa Dirasatu al Asaanid. Riadh: Maktabah al-Rusydi, 1983

Maidin, Muhammad Sabir. Ingkar Sunah Atau Hadis I Dalam Perspektif Historis. Makassar: Alauddin Pers, 2012.

Salahudin M. Agus dan Agus Suyadi, Ulumul Hadias. Bandung; Pustaka Setia, 2009.

Soetari, Endang, Ilmu Haidis: Kajian Riwayat dan Diraya.Bandung: Mimbar Pustaka, 2005.

Suprapta, Munzeir. Ilmu Hadis. Jakarta: Raja Grafindo Pustaka, 2003.

Thahhan, Mahmud al. Tafsir Musthalh al Hadis. Surabaya: Sirkat Bungkul Indah, 1985. 